\title{
Isolation and survey of L-asparaginase producing bacteria from soil
}

\author{
Mahmoud M. Nour El-Dein, Mohamed M. Mousa and Nashwa E. Metwally
}

Department of Plant and Microbiology, Faculty of Science, Damietta University, New Damietta

\begin{abstract}
L-asparaginase produced by various microorganisms which it used for the treatment of leukemia and starchy food industry. Screening of L-asparaginase producing bacteria from soil samples from Damietta different locations was done. The primary screening by qualitative methods using rapid plate assay determined that out of 25 isolates, 20 strains were producing Lasparaginase. The greatest pink color zones were observed for four bacterial isolates(A6, A11, $\mathrm{C} 11$ and C19) after $48 \mathrm{hrs}$. These four isolates that preliminary screened were grown in liquid media for static and submerged fermentation and then used for secondary screening by Nesslerization method. The best four isolates producing L-asparaginase were identified based on morphological, cultural and biochemical tests, as A6, C11 and C19 were identified as Bacillus species and A11 was identified as Staphylococcus species.
\end{abstract}

Key words : L-asparaginase, Bacillus, Staphylococcus.

\section{INTRODUCTION}

L-asparaginase was discovered by Clementi in 1922in serum of guinea pig (BadoeiDalfard, 2016).L-asparaginase (EC3.5.1.1) belongs to a group of homologous amidohydrolases family, that catalyst the hydrolysis of amino acid L-asparagine to L-aspartate and ammonia (Fernandes and Gregoriadis1997). L-asparaginase aminohydrolase has gained attention in recent years due to its important applications, as its use in pharmaceutical industry as an alternative for treatment of different cancers suchas acute lymphoblastic leukemia, malignant diseases ofthe lymphoid system and Hodgkin's lymphomas (Pieters et al., 2011). Also, this enzyme is used in food industry to prevent theacrylamide formation when foods are processed in high temperatures. This use is important because acrylamideis a neurotoxin classified as potentially carcinogenic to humans.

L-asparaginase is present in many animal tissues, plants, microorganisms and in the serum of certain rodents but not in mankind. Although L-asparaginases are broadly distributed among various living organisms, however, microorganisms like bacteria, fungi, yeast, actinomycetes and algae are very efficient producers and the better source of L-asparaginase, because they can be cultured easily and the extraction and the purification of L-asparaginase from them are also convenient, facilitating the large scale production (Patroet al.,2011). Lasparaginase from Escherichia coli produces two types of enzyme, L-asparaginase I (EC1), found in the cytoplasm and L-asparaginase II (EC2), with periplasmic origin (Cachumba et al., 2016). However, only the second one has anti-cancer activity, some studies described EC1 as a constitutive enzyme and EC2 as secreted only as a response to exposure tolow concentrations of nitrogen(Charbonneau et al., 2017).

Most of the microbial L-asparaginase is intracellular in the nature except few which are secreted outside the cell (Narayana,2008; Rajan et al., 2018). Extracellular L-asparaginase is more advantageous than intracellular type because of higher accumulation of enzyme in culture broth under normal conditions, easy extraction, and downstream processing (Amenaet al., 2010). 


\section{Mahmoud M. Nour El-Dein et al.}

Screening for bacteria producing L-asparaginase has been prospected by many methods. The activity of L-asparaginase is accompanied by increase in $\mathrm{pH}$ due to liberation of ammonia, presence of ammonia is used qualitatively and quantitatively to determine the enzyme activity (Mashburn and Wriston, 1963;Abdelrazek et al., 2019). So this study aims to isolation and screening of L-asparaginase producing bacteria from different Damietta soil samples.

\section{Sample collection}

\section{MATERIALS AND METHODS}

Soil samples were collected from different locations in Damietta Governorate. These soil samples were taken from places has an area of $1 \mathrm{~m}^{2}$ in clean plastic bags. All samples were immediately transported to microbiology laboratory, Botany and Microbiology Department, Faculty of Science, Damietta University for bacterial isolation. The soil samples were processed within 1-2 hours of collection (Steubing, 1993).

\section{Isolation and primary screening of L-asparaginase producing bacteria (qualitative assay)}

The bacteria were isolated by plating dilutions in sterile distilled water throughout weighting $10 \mathrm{~g}$ of each soil samples and putting in a $250 \mathrm{~mL}$ Erlenmeyer flask containing $90 \mathrm{~mL}$ of sterile distilled water and shaking for 15 minutes and these suspensions were considered as $10^{-1}$ dilutions (Bhat et al., 2015). Each sample were diluted in the range of $10^{-2}$ to $10^{-5}$ and 0.1 $\mathrm{ml}$ of diluents was spread on modified sterile Czapek's dox Agar medium (g/l)(glucose2.0, Lasparagine10.0, $\mathrm{KH}_{2} \mathrm{PO}_{4} 1.52, \mathrm{Na}_{2} \mathrm{HPO}_{4} .2 \mathrm{H}_{2} \mathrm{O} 6.0, \mathrm{MgSO}_{4} .7 \mathrm{H}_{2} \mathrm{O} 0.5, \mathrm{CaCl}_{2} .2 \mathrm{H}_{2} \mathrm{O} 0.5, \mathrm{NaCl}$ 0.5 , traces from $\mathrm{Cu}\left(\mathrm{NO}_{3}\right)_{2} .3 \mathrm{H}_{2} \mathrm{O}, \mathrm{ZnSO}_{4} .7 \mathrm{H}_{2} \mathrm{O}$ and $\mathrm{FeSO}_{4} .7 \mathrm{H}_{2} \mathrm{O}$, agar 15.0 and $\left.\mathrm{pH} 6.9 \pm 0.2\right)$ and incubated at $37^{\circ} \mathrm{C}$ for 24 hours in the static incubator. After incubation period, the developed single colonies of bacteria which varied in shape and color were picked up and purified by streaking on fresh nutrient agar plates. The purified bacterial isolates were regularly subcultured and stored on nutrient agar slants at $4^{\circ} \mathrm{C}$ (Bahig et al., 2008). Primary screening of Lasparaginase producing bacteria was performed by rapid plate assay (Gulati et al., 1997). Modified M9 medium(g/l) (peptone 3.0, lactose 3.0, L-asparagine 6.0, $\mathrm{KH}_{2} \mathrm{PO}_{4}$ 2.0, $\mathrm{MgSO}_{4} .7 \mathrm{H}_{2} \mathrm{O} 1.0, \mathrm{CaCl}_{2} .2 \mathrm{H}_{2} \mathrm{O} 1.0$, agar 15 and $\mathrm{pH} 6.5 \pm 0.2$ ) containing $0.005 \%$ phenol red indicator was inoculated by each bacterial colony then incubated at $37^{\circ} \mathrm{C}$ for $24-48 \mathrm{hrs}$.and plate wasn't inoculated work as control.

\section{Secondary screening of L-asparaginase producing bacteria (quantitative assay)}

Isolated microorganisms from the previous screening were cultured in different liquid media such as TGY-Broth with $1 \%$ asparagine at $\mathrm{pH7.0,Modified} \mathrm{M9} \mathrm{broth} \mathrm{medium} \mathrm{at} \mathrm{pH} 6.5$, Modified Czapek's dox broth medium at $\mathrm{pH} 6.9$ and Asparagine dextrose salts broth medium at $\mathrm{pH}$ 6.8in $250 \mathrm{ml}$ Erlenmeyer flasks. Uninoculated medium served as negative control. All experiments for quantitative screening were done in triplicate after incubation on a rotary shaker $\left(37^{\circ} \mathrm{C}, 75 \mathrm{rpm}\right)$ for $48 \mathrm{hrs}$. and static incubator $37^{\circ} \mathrm{C}$ for $48 \mathrm{hrs}$, the culture broth was centrifuged at 7,000 rpm for $10 \mathrm{~min}$, supernatants were collected and enzyme assay was done by nesslerization (Imada et al., 1973; Benchamin et al., 2019).

\section{L-asparaginase assay}

The L-asparaginase activity was determined by hydrolysis of L-asparagine to release the ammonia which was measured by using Nessler's reaction (Yim \& Kim 2019). A mixture of 0.1 $\mathrm{ml}$ enzyme extract, $0.2 \mathrm{ml}$ of $0.05 \mathrm{M}$ Tris- $\mathrm{HCl}$ buffer ( $\mathrm{pH} \mathrm{8.6)}$ and $1.7 \mathrm{ml}$ of $0.01 \mathrm{M}$ L-asparagine 


\section{Isolation and survey of L-asparaginase producing bacteria from soil}

was incubated for $10 \mathrm{~min}$ at $37^{\circ} \mathrm{C}$. The reaction was stopped by the addition of $0.5 \mathrm{ml}$ of $1.5 \mathrm{M}$ trichloroacetic acid (TCA), and then centrifugation at $1000 \mathrm{rpm}, 0.5 \mathrm{ml}$ of supernatant was diluted to $7 \mathrm{ml}$ with distilled water and treated with $1 \mathrm{ml}$ of Nessler's reagent. The color reaction was allowed to develop for $10 \mathrm{~min}$ and absorbance read at $480 \mathrm{~nm}$ with a spectrophotometer (Kishor et al., 2015). One international unit (IU) of L-asparaginase was defined as amount of enzyme that liberates one $\mu$ mole of ammonia per minute (Prakasham et al., 2007).

\section{Protein Estimation}

Total protein contents were estimated according to method described by Bradford (1976).

\section{Identification of the selected bacterial strains}

The best L-asparaginase producing bacteria were identified listed in according to Bergey's manual of determinative bacteriology (Sneath et al., 1986).

\section{Statistical analysis}

Data were statistically analyzed for variance and least significant difference using oneway analysis of variance (ANOVA). A software system SPSS version 22 was used for these calculations.

\section{RESULTS \\ Isolation and primary screening of L-asparaginase producing bacteria}

25 bacterial isolates were isolated from six soil samples collected from different locations of Damietta Governorate (Table 1). Based on rapid plate assay, it was observed that among 25 isolates, 20 bacterial strains showed pink color on modified M9 medium for L-asparaginase production. Four isolates from L-asparaginase producing bacteria showed better pink color zone more than any other isolates (Table 2 and Fig. 1), so these four isolates were used for fermentation study to determine the crude enzyme activity.

\section{Secondary screeningof L-asparaginase producing bacteria}

Static fermentation was performed by inoculating the four isolates bacteria(A6, A11, C11 and C19) into modified M9 medium at specific time interval of 12, 24, 36, 48, 60 and $72 \mathrm{hrs}$. and the results of enzyme activity and specific activity (Figs. $3 \& 4$ ).

Enzyme activity and specific activity were increased after $48 \mathrm{hrs}$. for all four bacterial isolates and the isolate A6 showed maximum enzyme activity $(0.454 \mathrm{U} / \mathrm{ml})$ and specific activity (6.98U/mg) within 48hrs.

Submerged fermentation was performed by inoculating isolates bacteria(A6, A11, C11 and (19) bacterial isolates into different four media as follows: TGY-Broth with $1 \%$ asparagine, modified M9 broth medium, modified Czapek's dox broth medium and asparagine dextrose salts broth medium at specific time interval of 24, 48, 72 and $96 \mathrm{hrs}$. and each sample was analyzed for enzyme activity and specific activity. The enzyme activity and specific activity increased after incubated for $48 \mathrm{hrs}$. for all isolates into different four media. The isolate A6 strain showed maximum enzyme activity $(0.767 \mathrm{U} / \mathrm{ml})$ and specific activity $(7.89 \mathrm{U} / \mathrm{mg})$ after incubated for 48 hrs. into TGY-Broth with $1 \%$ asparagine (Figs. 5 \& 6). 


\section{Mahmoud M. Nour El-Dein et al.}

\section{Identification of the four bacterial strains}

The four isolated bacteria that have ability to produce L-asparaginase, were identified based on morphological, cultural and biochemical tests. A6, C11 and C19were gram positive bacteria with rod shape and endospore forming, catalase - positive, oxidase - negative and starch hydrolysis - positive so there were identified as Bacillus species when A11 was gram positive bacteria with cocci arranged in grape like shape and not endospore forming, catalase - positive, oxidase - negative and starch hydrolysis - positive so it was identified as Staphylococcus species(Table 3 and Fig. 2).

Table 1: Sites for samples from different locations of Damietta Governorate.

\begin{tabular}{|c|c|c|}
\hline No. & Sample code & Location \\
\hline 1 & S & Agriculture sand soil from Gamasa \\
\hline 2 & Sc & Agriculture soil from Kafr Shehata \\
\hline 3 & Cd & Agriculture soil from Kafr saad \\
\hline 4 & A & Bank soil from Nile River \\
\hline 5 & C & Bank soil from Ezbet El-Borge canal \\
\hline 6 & G & Garden soil from New Damietta Garden \\
\hline
\end{tabular}

Table 2:Qualitative data of L-asparaginase production by bacteria during primary screening.

\begin{tabular}{|c|c|c|c|c|c|}
\hline No. & $\begin{array}{c}\text { Isolates } \\
\text { code }\end{array}$ & Pink color zone & No. & $\begin{array}{c}\text { Isolates } \\
\text { code }\end{array}$ & Pink color zone \\
\hline 1 & S1 & Moderate zone & 14 & A6 & Large zone \\
\hline 2 & S2 & No zone & 15 & A10 & Small zone \\
\hline 3 & S3 & Moderate zone & 16 & A11 & Large zone \\
\hline 4 & S4 & Small zone & 17 & A18 & Small zone \\
\hline 5 & S5 & Moderate zone & 18 & A23 & Moderate zone \\
\hline 6 & Sc6 & Very small zone & 19 & C1 & No zone \\
\hline 7 & Sc7 & Small zone & 20 & C4 & Small zone \\
\hline 8 & Sc8 & Small zone & 21 & C5 & No zone \\
\hline 9 & Cd9 & Moderate zone & 22 & C10 & Very small zone \\
\hline 10 & Cd10 & Very small zone & 23 & C11 & Large zone \\
\hline 11 & Cd11 & No zone & 24 & C19 & Large zone \\
\hline 12 & G1 & Small zone & 25 & C20 & No zone \\
\hline 13 & G18 & Very small zone & & & \\
\hline
\end{tabular}


Isolation and survey of L-asparaginase producing bacteria from soil

Table 3: Microbiological characteristics of the best L-asparaginase producing bacteria.

\begin{tabular}{|c|c|c|c|c|c|}
\hline \multicolumn{6}{|c|}{ Cultural characters on nutrient agar } \\
\hline \multicolumn{2}{|c|}{ Character } & A6 & A11 & C11 & C19 \\
\hline \multicolumn{2}{|c|}{ Shape } & Punctiform & Circular & Punctiform & Circular \\
\hline \multicolumn{2}{|c|}{ Edge } & Entire & Entire & Entire & Looped \\
\hline \multicolumn{2}{|c|}{ Elevation } & convex & convex & convex & convex \\
\hline \multicolumn{2}{|c|}{ Surface } & Smooth & Smooth & Smooth & Smooth \\
\hline \multicolumn{2}{|c|}{ Pigmentation } & No pigmented & No pigmented & No pigmented & No pigmented \\
\hline \multirow{2}{*}{$\begin{array}{c}\text { Optical } \\
\text { properties }\end{array}$} & Color & Creamy & Creamy & Creamy & Creamy \\
\hline & Opacity & Translucent & Opaque & Translucent & Translucent \\
\hline \multicolumn{6}{|c|}{ Morphological characters } \\
\hline \multicolumn{2}{|c|}{ Gram stain } & Positive & Positive & Positive & Positive \\
\hline \multicolumn{2}{|c|}{ Shape } & Rod & Cocci & Rod & Rod \\
\hline \multicolumn{2}{|c|}{ Cell diameter $(\mu \mathrm{m})$} & $2.55 \mu \mathrm{m}$ & $1.7 \mu \mathrm{m}$ & $4.08 \mu \mathrm{m}$ & $3.4 \mu \mathrm{m}$ \\
\hline \multicolumn{2}{|c|}{ Spore stain } & Spore forming & Absent & Spore forming & Spore forming \\
\hline \multicolumn{2}{|c|}{ Acid fast stain } & Negative & Negative & Negative & Negative \\
\hline \multicolumn{6}{|c|}{ Biochemical characters } \\
\hline \multicolumn{2}{|c|}{ Oxidase test } & Negative & Negative & Negative & Negative \\
\hline \multicolumn{2}{|c|}{ Catalase test } & Positive & Positive & Positive & Positive \\
\hline \multicolumn{2}{|c|}{ Starch hydrolysis } & Positive & Positive & Positive & Positive \\
\hline \multicolumn{2}{|c|}{ Indoleproduction test } & Negative & Negative & Negative & Negative \\
\hline \multicolumn{2}{|c|}{ Methyl red test } & Negative & Positive & Positive & Negative \\
\hline \multicolumn{2}{|c|}{ Voges-Proskauer test } & Positive & Positive & Positive & Positive \\
\hline \multicolumn{2}{|c|}{ Citrate utilization test } & Negative & Negative & Positive & Negative \\
\hline \multicolumn{2}{|c|}{$6.5 \% \mathrm{NaCl}$} & Traces of growth & Growth & Growth & Growth \\
\hline \multicolumn{2}{|c|}{ Lactose fermentation } & Negative & Positive & Positive & Negative \\
\hline \multicolumn{2}{|c|}{ Gas production } & Negative & Positive & Positive & Negative \\
\hline \multicolumn{2}{|c|}{ Glucose fermentation } & Positive & Positive & Positive & Positive \\
\hline \multicolumn{2}{|c|}{ Mannitol fermentation } & Positive & Negative & Positive & Positive \\
\hline \multicolumn{2}{|c|}{ Arabinose fermentation } & Negative & Negative & Positive & Positive \\
\hline \multicolumn{2}{|c|}{ Maltose fermentation } & Negative & Positive & Positive & Positive \\
\hline
\end{tabular}

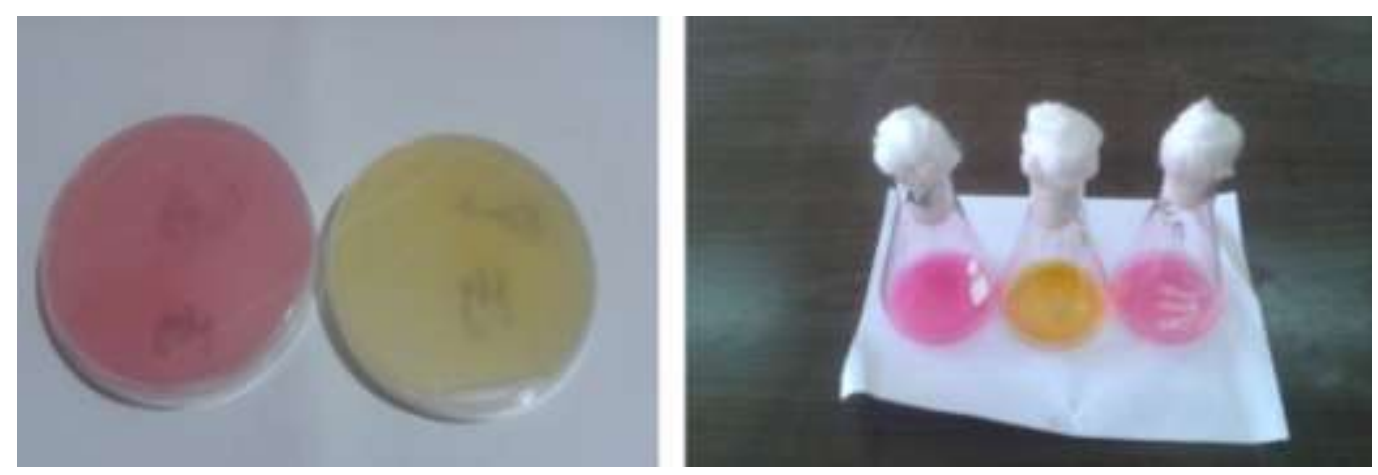

Fig. 1:Primary screeningshowing pink color of M9 modified media by C19, A6 and A11. 
Mahmoud M. Nour El-Dein et al.
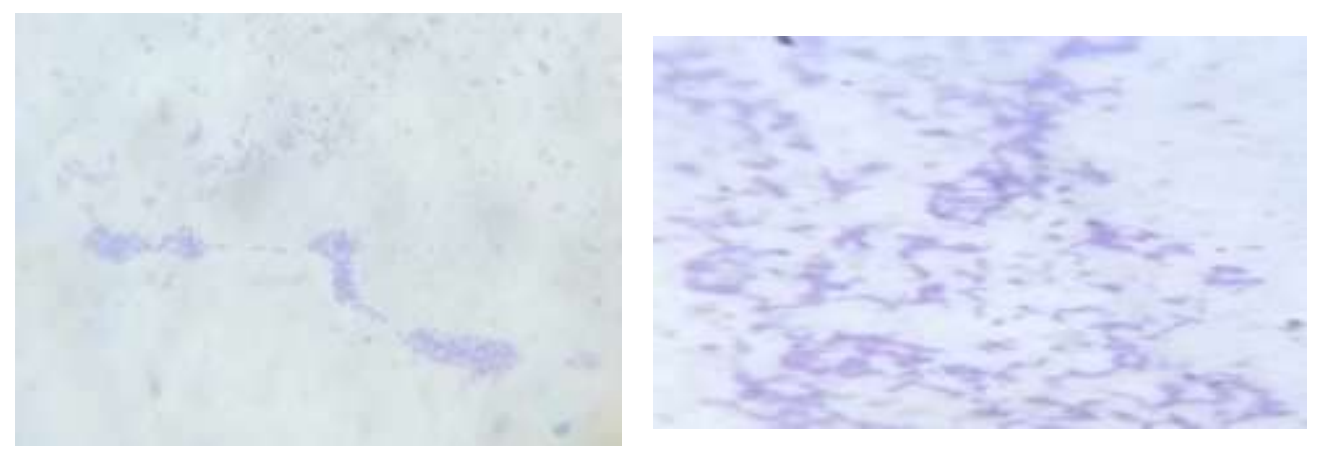

Fig. 2: Gram stain for two L-asparaginase producing bacteria A11 and A6 respectively.

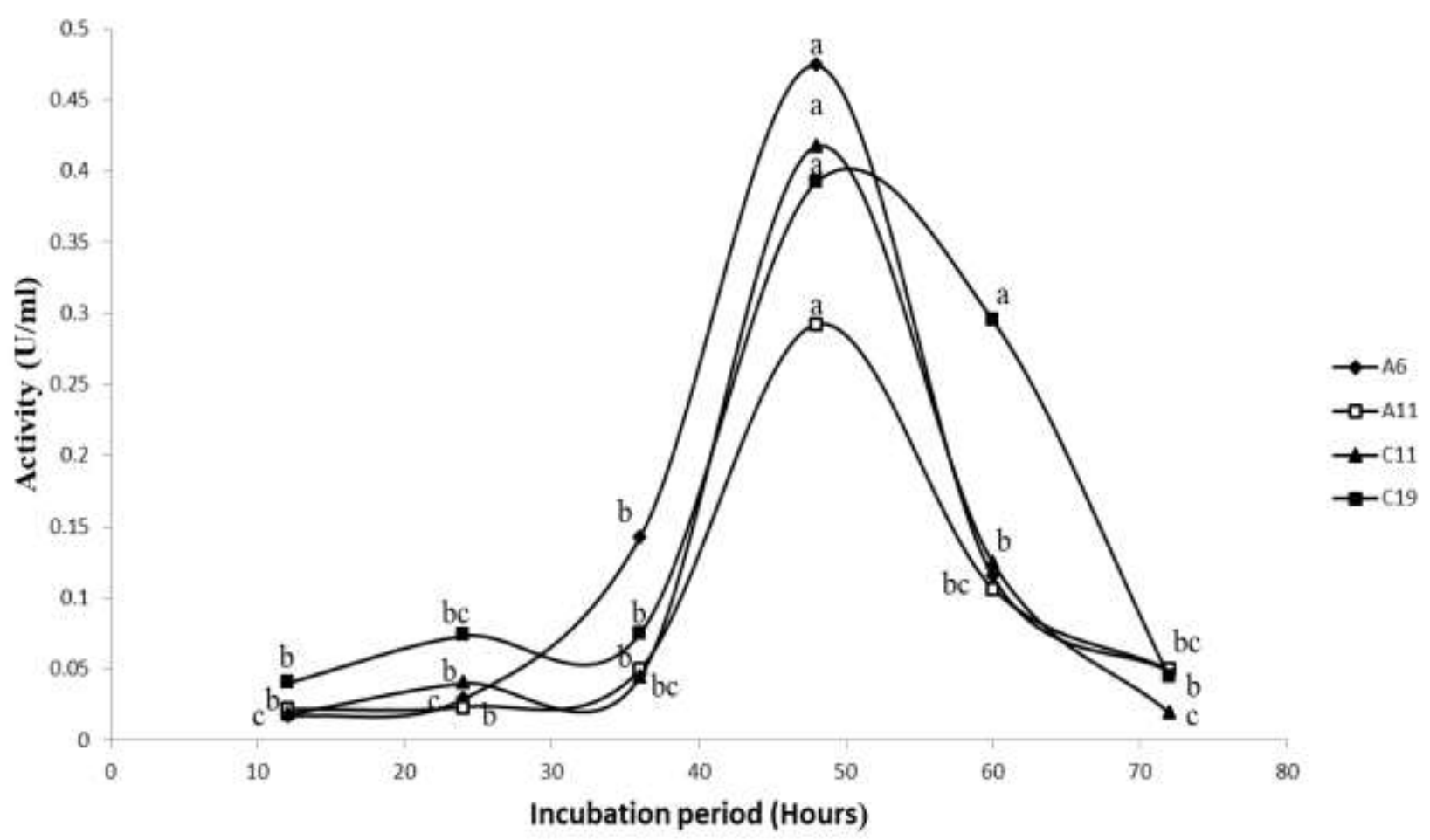

Fig. 3:Activity of L-asparaginase producing bacteria in static fermentation on M9 modified media; different letters indicate different significant values. 
Isolation and survey of L-asparaginase producing bacteria from soil

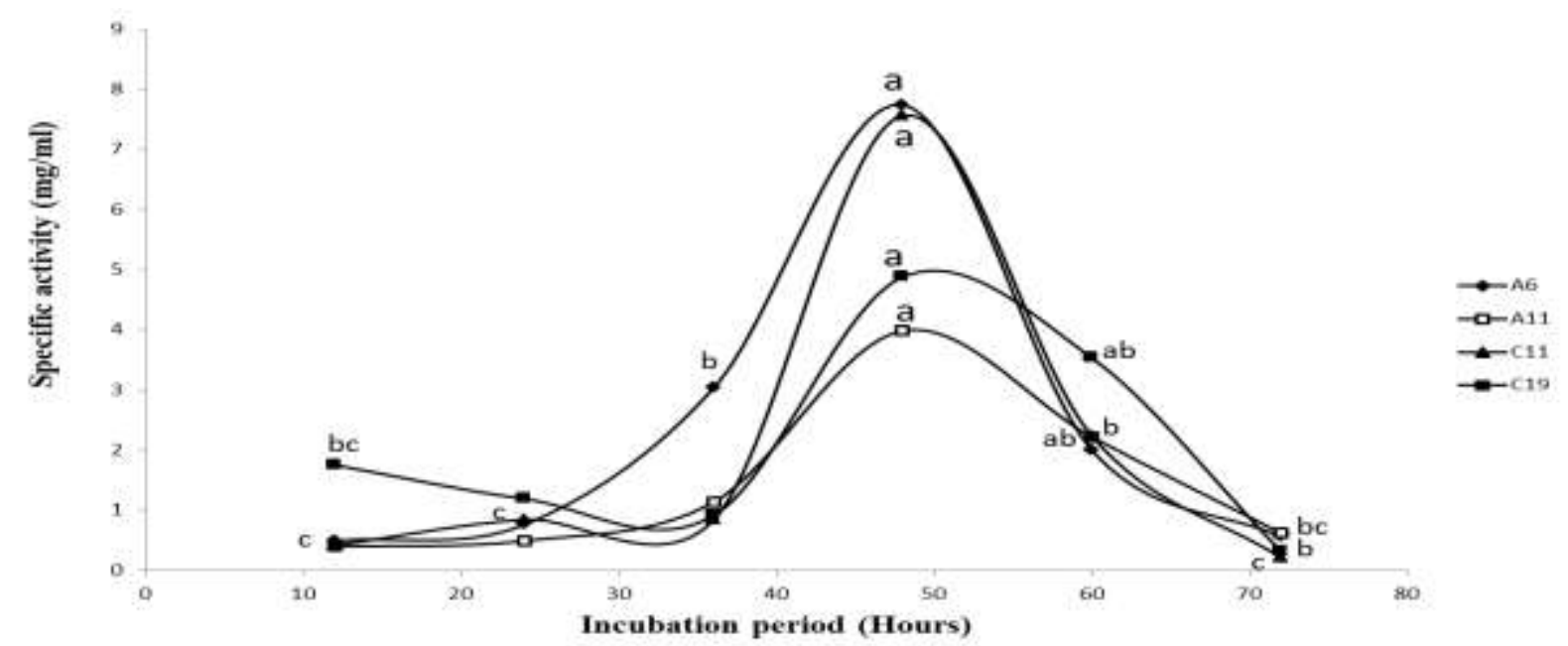

Fi.g. 4:Specific activities of L-asparaginase producing bacteria in static fermentation on M9 modified media;different letters indicate different significant values.

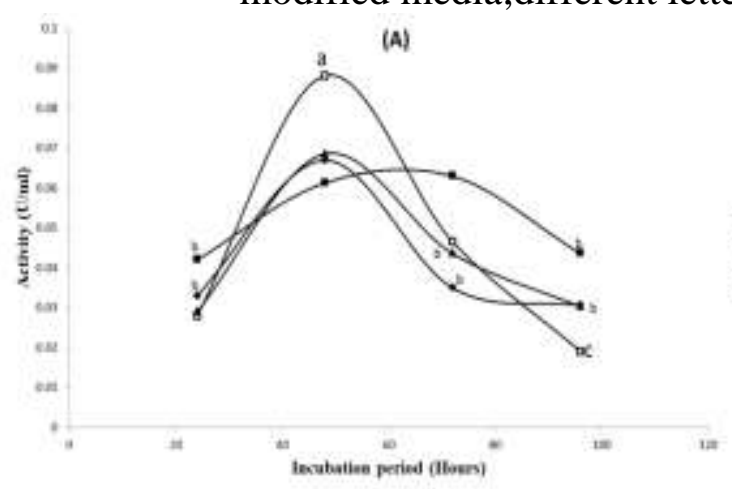

Modified Czapek's dox broth medium

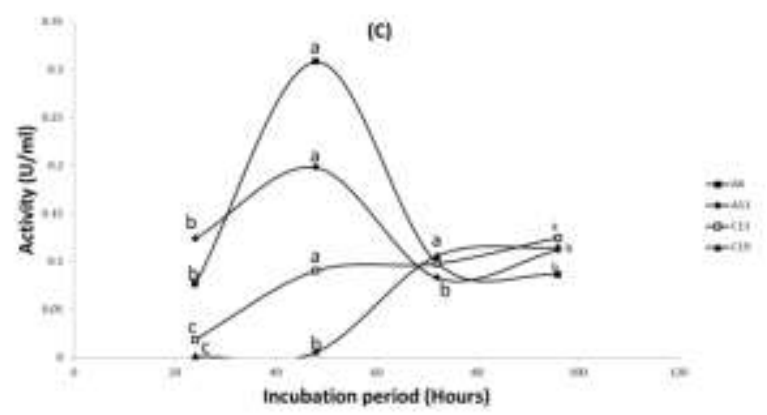

Asparagine dextrose salts broth medium

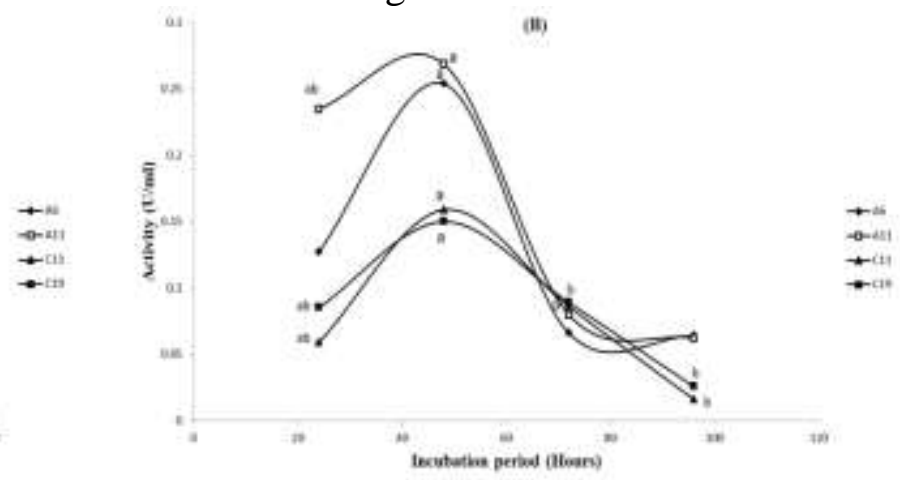

Modified M9 broth medium

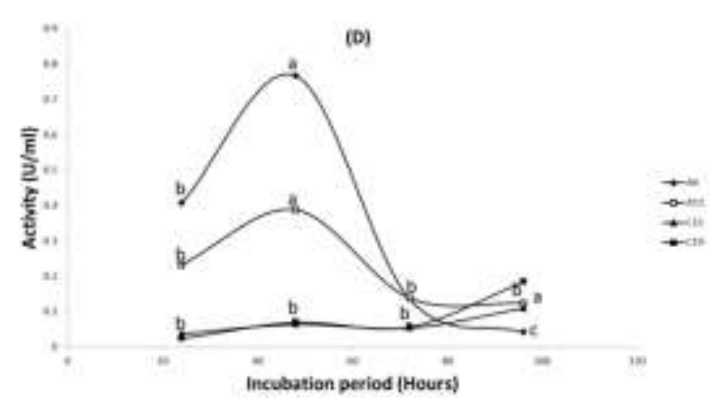

TGY-Broth with $1 \%$ asparagine

Fig. 5:Activity of L-asparaginase producing bacteria in submerged fermentation on different media; different letters indicate different significant values. 
Mahmoud M. Nour El-Dein et al.

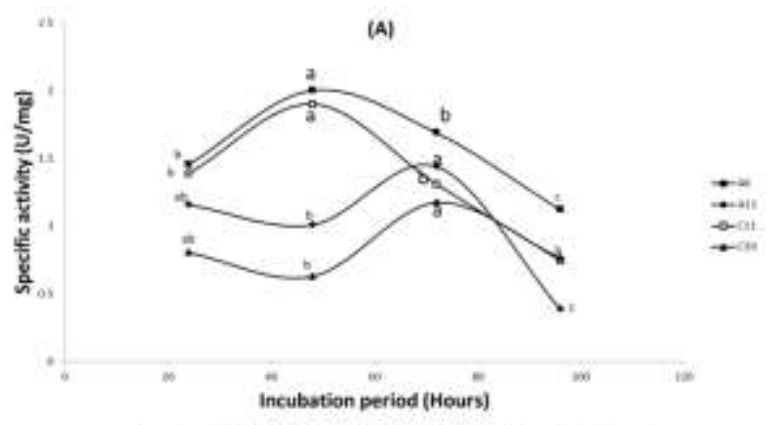

Modified Czapek's dox broth medium

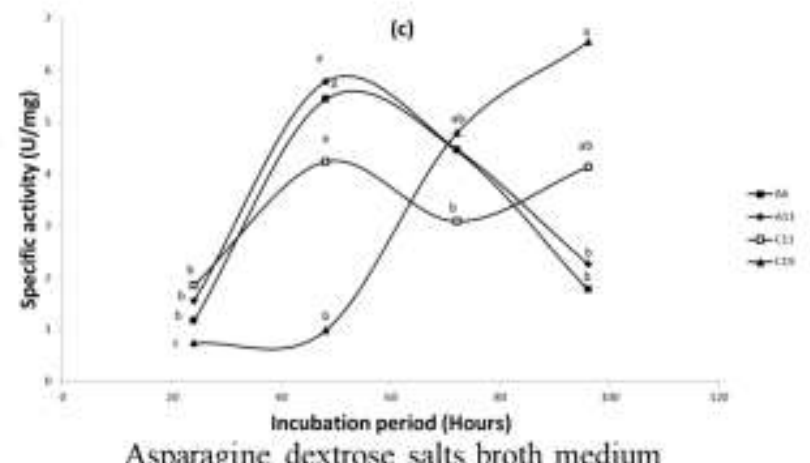

Asparagine dextrose salts broth medium

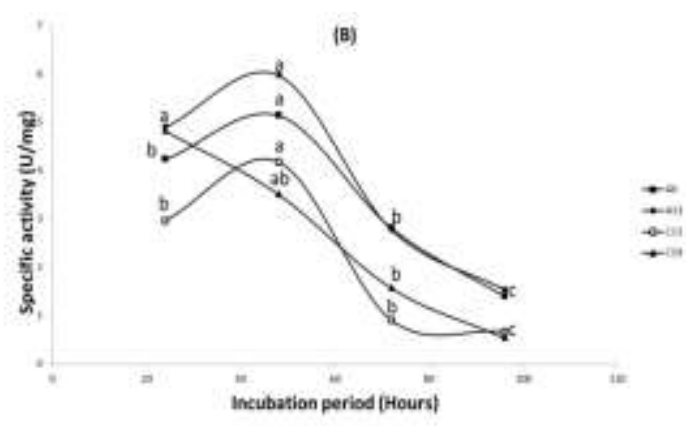

Modified M9 broth medium

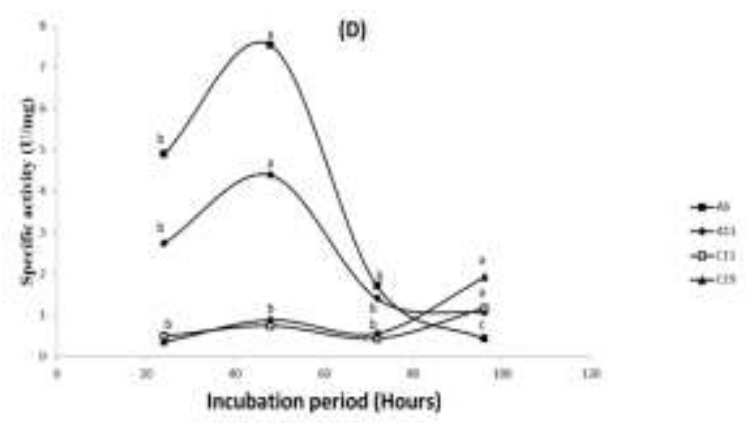

TGY-Broth with $1 \%$ asparagine

Fig. 6: Specific activities of L-asparaginase producing bacteria in submerged fermentation on different media; different letters indicate different significant values.

\section{DISCUSSION}

Recently, L-Asparaginase studying has gained much attention for its anti-carcinogenic potential. Several authors scripted the use of L-asparaginase in cancer therapy (Pieters et al., 2011 and Tong et al., 2013). In the present study twenty bacterial strains were isolated from six different soil samples have the ability to produce L-asparaginase. This may be attributed to the fact that soil is rich source for potential enzyme producing organisms (Geisseler et al., 2010).

The result of screening test indicated that L-asparaginase producing bacteria had able to hydrolysis L-asparagine to L-aspartic acid and ammonia that further reacts with water to produce $\mathrm{NH}_{4} \mathrm{OH}$, hence the $\mathrm{pH}$ of the medium is basic so the medium color change from yellow to pink.

Gulati et al. (1997) proved the color transformation was due to L-asparaginase production accordance with this study. The bacterial isolates that had the greatest L-asparaginase activity were identified as Bacillus spp. and Staphylococcus spp. that is similar to those described by Kamble and Khade (2012) who reported that Bacillus spp. were a good asparaginase producing bacteria.The four bacterial isolates (A6, A11, C11 and C19) showed the maximum extracellular L-asparaginase activity with submerged fermentation in tryptone glucose yeast extract with $1 \%$ asparagine medium. Similar results were obtained by Sudha et al., (2016).

In this study the isolated A6 showed $7.89 \mathrm{U} / \mathrm{mg}$ of L-asparaginase specific activity with $0.097 \mathrm{mg} / \mathrm{ml}$ of a total protein concentration. Kothari and Deshmukh (2014) found 1.79U/mg with $1.33 \mathrm{mg} / \mathrm{ml}$ of a total protein concentration. Roberts et al. (1968) had achieved 0.950U/mg 


\section{Isolation and survey of L-asparaginase producing bacteria from soil}

of specific activity from E.coli HAP strain, when compared to the earlier reports, our study more $50 \%$ of specific activity to be increased by using Bacillus sp. (A6).

The isolate (A6) showed effective production with the medium containing three nitrogen sources (asparagine, yeast and tryptone) and glucose as sole carbon source at $37^{\circ} \mathrm{C}$ and $\mathrm{pH} 7.0$ for $48 \mathrm{hrs}$. In a previous report, the maximum L-asparaginase activity observed on the media contain peptone as sole nitrogen source and glucose as sole carbon source at $37{ }^{\circ} \mathrm{C}$ and $\mathrm{pH} 8.0$ for 72 hrs. (Mohapatra et al., 1995).

Victoria and Krishnaveni (2010) documented that 10 Staphylococcal species showed pink zones around each colony in rapid plate assay on M9 modified medium. That is similar to this study; the isolate (A11) showed large pink zone on modified M9 medium these isolate (A11) was identified as Staphylococcus species.

In this study; when different four media were used in screening, we were found the tryptone glucose yeast extract with $1 \%$ L-asparagine is the best media for L-asparaginase production, this may by present of three different nitrogen sources and glucose as carbon source which induced the bacterial growth that associated with L-asparaginase production (Hadapsar, 2010).

The four isolates (A6, A11, C11 and C19) have the ability to produce extracellular Lasparaginase on submerged fermentation on tryptone glucose yeast extract with $1 \%$ asparagine at $37^{\circ} \mathrm{C}$ and $\mathrm{pH} 7.0$ for $48 \mathrm{hrs}$., this isolates (A6, C11 and C19) were identified as Bacillus species, the isolate (A11) was identified as Staphylococcus species. These are good preliminary results calling to complete the search on these isolates.

\section{REFERENCES}

Abdelrazek, N. A.; Elkhatib, W.F.; Raafat, M. M. and Aboulwafa, M. M. (2019). Experimental and bioinformatics study for production of L-asparaginase from Bacillus licheniformis: a promising enzyme for medical application. AMB Express, 9(1):39.doi: 10.1186/s13568019-0751-3.

Amena, S.; Vishalakshi, N.; Prabhakar, M.; Dayanand, A. and Lingappa, K. (2010). Production, purification and characterization of L-asparaginase from Streptomyces gulbargensis. Brazil. J. Microbiol., 41(1): 173-178.

Badoei-Dalfard, A. (2016). L-asparaginase production in the Pseudomonas pseudoalcaligenes strain JHS-71 isolated from Jooshan Hot-spring. Molecular Biol.Res. Communications, 5(1): 1-10.

Bahig, A. E.; Aly, E. A.; Khaled, A. A. and Amel, K.A. (2008). Isolation, characterization and application of bacterial population from agricultural soil at Sohag Province, Egypt. Malaysian J. Microbiol., 4(2): 42-50.

Benchamin, D., Sreejai, R., Athira, L., Jensy Roshan, F., Sujitha, S., \& Kurup, B. S. (2019). Production and characterization of L-Asparaginase isolated from Aspergillus fumigatus.The Pharma Innovation Journal, 8(3): 220-223

Bhat, M.R.; Nair, J.S. and Marar, T. (2015). Isolation and identification of L-asparaginase producing Salinicoccus sp. M KJ997975 from soil microbial flora. Int. J. Pharmac. Sci. Res., 6(8): 3599-3604.

Bradford, M.M. (1976). A rapid and sensitive method for the quantitation of microgram quantities of protein utilizing the principle of protein-dye binding. Analytical Biochemistry, 72(1-2): 248-254. 


\section{Mahmoud M. Nour El-Dein et al.}

Cachumba, J. J. M.; Antunes, F.A.F.; Peres, G.F.D.; Brumano, L.P.; Dos Santos, J.C. and Da Silva, S.S. (2016). Current applications and different approaches for microbial Lasparaginase production. Brazilian J. Microbiol., 47: 77-85.

Charbonneau, D. M.; Aube, A.; Rachel, N. M.; Guerrero, V.; Delorme, K.; Breault-Turcot, J. and Pelletier, J.N. (2017). Development of Escherichia coli Asparaginase II for Immunosensing: A Trade-Off between Receptor Density and Sensing Efficiency. American Chemical Society Omega, 2(5): 2114-2125.

Clementi, A. (1922). La désamidation enzymatique de l'asparagine chez les différentes espéces animales et la signification physio logique de sa presence dans l'organisme. Archives Int. de Physiol., 19(4): 369-398.

Fernandes, A. I. and Gregoriadis, G. (1997). Polysialylated asparaginase: preparation, activity and pharmacokinetics. Biochimica et Biophysica Acta (BBA)-Protein Structure and Molecular Enzymology, 1341(1): 26-34.

Geisseler, D.; Horwath, W. R.; Joergensen, R.G. and Ludwig, B. (2010). Pathways of nitrogen utilization by soil microorganisms-a review. Soil Biol. Biochem., 42(12): 2058-2067.

Gulati, R.; Saxena, R. K. and Gupta, R. (1997). A rapid plate assay for screening 1-asparaginase producing micro-organisms. Letters in Appl. Microbiol., 24(1): 23-26.

Hadapsar, P. (2010). Isolation, optimization and production of L-asparaginase from coliform bacteria. Asian Journal of Biotechnology, 2(3): 169-177.

Imada, A.; Igarasi, S.; Nakahama, K. and Tubaki, K. (1973). Formation of L-asparaginase by Fusarium species. Microbiol., 75(2): 269-273.

Kamble, K. D. and Khade, P.J. (2012). Studies on antineoplastic enzyme producing bacteria from soil.International J. Biomed. Res., 2: 94-99.

Kishor, D., Nimkande, Zia Khan, H., Shankar Mular, M., \& Sangita Kunjwani, S. (2015). Isolation, Purification \& Characterization of L-Asparaginase from dry seeds of Pisum sativum and Vigna radiata. IJAR, 1(7): 628-631.

Kothari, P. and Deshmukh, D.V. (2014). Isolation and purification of anti-tumor enzyme LAsparaginase from Soil isolates. Int. J. Pharmacognosy, 1(6): 384-388.

Mashburn, L.T. and Wriston Jr,J.C. (1963). Tumor inhibitory effect of Lasparaginase. Biochemical and Biophysical Research Communications, 12(1): 50-55.

Mohapatra, B. R.; Sani, R.K., and Banerjee, U.C. (1995). Characterization of L-asparaginase from Bacillus sp. isolated from an intertidal marine alga (Sargassum sp.). Letters in Appl. Microbiol., 21(6): 380-383.

Narayana, K. J. P.; Kumar, K. G. and Vijayalakshmi, M. (2008). L-asparaginase production by Streptomyces albidoflavus. Ind. J. Microbiol., 48(3): 331-336.

Patro, K. K. R.; Satpathy, S. and Gupta, N. (2011). Evaluation of some fungi for L-asparaginase production. Ind. J. Fundamental and Appl. Life Sci., 1(4): 219-221.

Pieters, R.; Hunger, S.P.; Boos, J.; Rizzari, C.; Silverman, L.; Baruchel, A. and Pui, C.H. (2011). L-asparaginase treatment in acute lymphoblastic leukemia: a focus on Erwinia asparaginase. Cancer, 117(2): 238-249.

Prakasham, R.S.; Rao, C.S.; Rao, R.S.; Lakshmi, G.S. and Sarma, P. N. (2007). L-asparaginase production by isolated Staphylococcus sp.-6A: design of experiment considering interaction effect for process parameter optimization. J. Appl. Microbiol., 102(5): 13821391.

Rajan, S. and Deivasigamani, B. (2018). Screening, Production and Characterization of extracellular glutaminase free L-Asparaginase producing endo-symbiontic bacteria from 


\section{Isolation and survey of L-asparaginase producing bacteria from soil}

the gut of Mugil cephalus (Mullet fish). Asian J. Pharmacy and Pharmacol., 4(3): 288292.

Roberts, J.; Burson, G. and Hill, J. M. (1968). New procedures for purification of Lasparaginase with high yield from Escherichia coli. J. Bacteriol. 95(6): 2117-2123.

Sneath, P. H.; Mair, N.S.; Sharpe, M.E. and Holt, J.G. (1986). Bergey's manual of systematic bacteriology. Volume 2. Williams \&Wilkins.

Steubing, P.M. (1993). Isolation of an unknown bacterium from soil. Tested studies for laboratory teaching, 14, pp 81-114 in ABLE.

Sudha, K.; Rani john and Sivansakari, T.R. (2016). Extracellular L-asparaginase Production by halotolerate strain of Enterobacter hormaechei Isolated. Int. J. Advance Res., 5: 26192625.

Tong, W.H.; van der Sluis; I.M. ; Alleman, C.J.; van Litsenburg, R.R.; Kaspers, G.J.; Pieters, R. and Uyl-de Groot, C.A. (2013).Cost-analysis of treatment of childhood acute lymphoblastic leukemia with asparaginase preparations: the impact of expensive chemotherapy. Haematologica, 98: 753-759.

Victoria, J. and Krishnaveni, K. (2010). L-asparaginase activity of Staphylococcus aureus from bat faeces. J. Ecobiol., 26(1/2): 141-145.

Yim, S. and Kim, M. (2019). Purification and characterization of thermostable 1-asparaginase from Bacillus amyloliquefaciens MKSE in Korean soybean paste. LWT - Food Science and Technology, 109: 415-421.

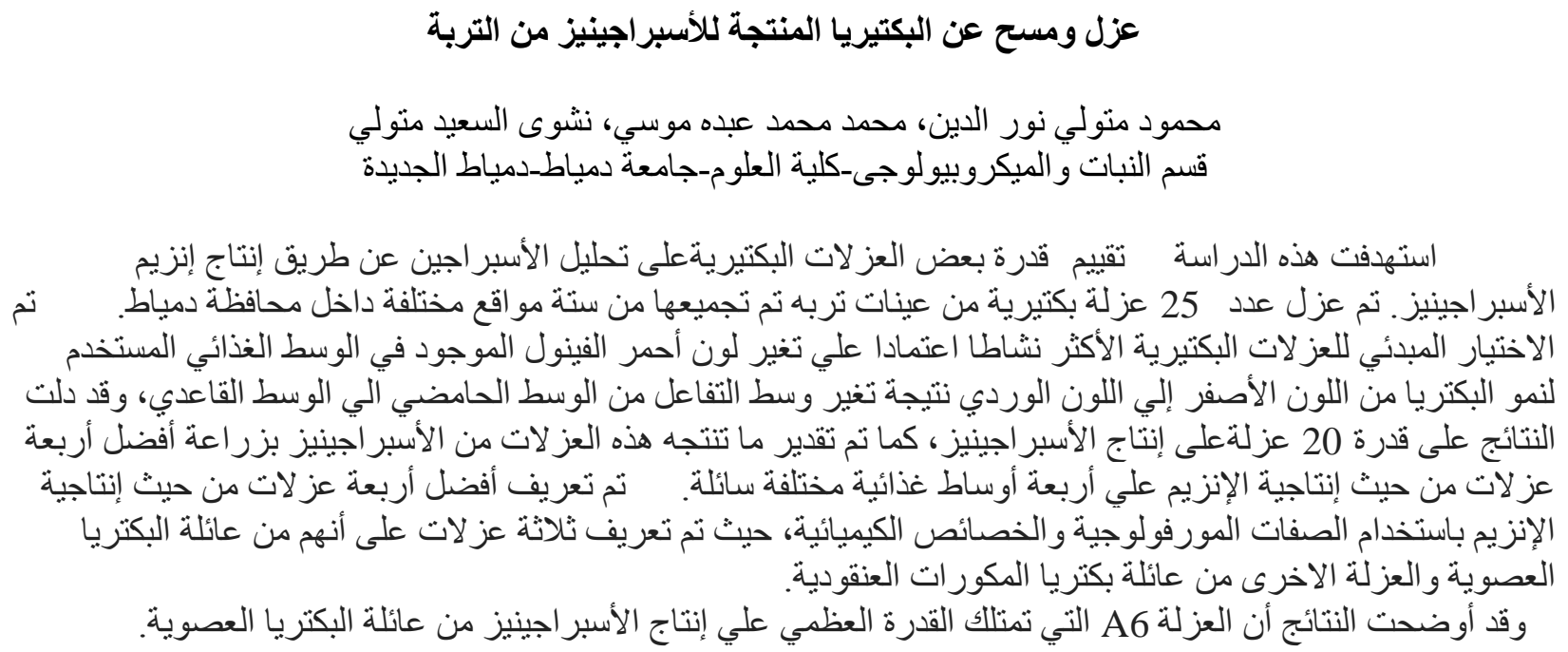

